\title{
MENUJU PERUMUSAN PERANSERTA ARKEOLOGI DALAM PELAKSANAAN ANALISIS MENGENAI DAMPAK LINGKUNGAN
}

\author{
Oleh: Bugie M.H. Kusumohartono
}

1.

1.1. Pada abad ke-19, revolusi industri telah berlangsung sedemikian intensif di Inggris. Bersamaan dengan itu manusia mulai secara serius memperhatikan limbah yang dihasilkan oleh industri tersebut, serta pencemaran yang mengikutinya. Limbah dan pencemarah tersebut meninggi intensitas gangguannya selaras dengan peningkatan dan pengembangan berbagai kegiatan industri. Pada akhirnya, tahap demi tahap, dilahirkanlah berbagai ketentuan dan peraturan mengenai pengendalian gangguan limbah, khususnya yang berpotensi memasok pencemaran terhadap lingkungan hidup manusia.

Perhatian dunia secara menyeluruh terhadap masalah lingkungan yang timbul, pada gilirannya mendapatkan muara pada konperensi $\mathrm{PBB}$ tentang lingkungan hidup manusia di Stockholm, yang berlangsung antara tanggal 5 sampai dengan 16 Juni 1972. Sampai saat ini, tanggal 5 Juni ditetapkan sebagai Hari Lingkungan Sedunia, karena konperensi tersebut dipandang memberikan sumbangan yang berharga bagi upaya pelestarian lingkungan hidup.

Sebenarnya beberapa negara, terutama negara industri, telah melangkah/lebih maju dalam menangani masalah lingkungan. Amerika Serikat, misalnya, telah memiliki undang-undang lingkungan yang disebut National Environmental Policy Act (NEPA) sejak 1 Januari 1970. Undang-undang serupa milik Indonesia baru lahir 10 tahun kemudian sejak berlangsungnya konperensi Stockholm. Produk perundangan tersebut adalah Undang-undang Republik Indonesia Nomor 4 Tahun 1982 tentang Ketentuan-ketentuan Pokok Pengelolaan Lingkungan Hidup (Kantor Menteri Negara Pengawasan Pembangunan dan Lingkungan Hidup, 1982), atau terkenal dengan sebutan UULH. 
Sebagaimana juga NEPA. UULH diikuti oleh berbagai peraturan pemerintah yang dimaksudkan agar UULH tersebut dapat berfungsi secara operasional. Pada tanggal 5 Juni 1986, pemerintah menetapkan Peraturan Pemerintah (PP) Republik Indonesia Nomor 29 Tahun 1986 tentang Analisis Mengenai Dampak Lingkungan sebagai kelanjutan dari isi pasal 16 UULH (Kantor Menteri Negara Kependudukan dan Lingkungan Hidup, 1984), atau yang populer dengan sebutan PP 29.

PP 29 menggariskan ketentuan untuk penyusunan suatu analisis mengenai dampak lingkungan bagi setiap pemrakarsa kegiatan (investor) sebelum melaksanakan suatu kegiatan pembangunan yang memberikan dampak penting bagi lingkungan (ps. 2 dan 3). PP tersebut akan berlaku efektif mulai tanggal 5 Juni 1987.

1.2. Bagi perencanaan suatu kegiatan pembangunan, ANDAL merupakan salah satu komponen dari kegiatan studi kelayakan (feasibility study), di luar komponen yang lain yaitu teknis dan ekonomis (ps. 6). Melalui ANDAL, diharapkan prakiraan dampak negatif suatu kegiatan pembangunan dapat disiapkan penanggulangannya, serta pengembangan dampak positif yang diperhitungkan akan timbul. Penyusunan ANDAL pada tahap rencana kegiatan akan membantu pemrakarsa kegiatan memperoleh pemahaman 'jang luas dan mendalam mengenai berbagai aspek lingkungan yang terkait, sehingga dapat diambil keputusan yang optimal dari berbagai pilihan kegiatan yang tersedia. Selain itu, hasil ANDAL akan menghindarkan pemrakarsa kegiatan dari tuntutan yang timbul kemudian, akibat dampak negatif yang dihasilkan oleh kegiatan yang telah berjalan.

Dalam peristilahan dan kegiatan penyusunannya, ANDAL memiliki aúa pengertian. Paparan di atas adalah ANDAL. dalam pengertian yang pertama, yaitu analisis mengenai dampak lingkungan. Sedang pada pengertian kedua; analisis dampak lingkungan (ANDAL) adalah salah satu aktivitas dalam ANDAL (pengertian pertama). Keseluruhan aktivitas dalam ANDAL (pengertian pertama) adalah meliputi: 1. Penyajian Informasi Lingkungan (PIL); 2. Kerangka Acuan 
(KA) bagi ANDAL: 3 Analisis Dampak Lingkungan (ANDAL):4. Rencana Pengelolaan Lingkungan (RKL). dan 5 Rencana Pemantauan Lingkungan (RPL).

PP 29 juga menggariskan penyusunan evaluasi dampak lingkungan bagi kegiatan-kegiatan pembangunan yang telah berjalan sebelum PP ini diberlakukan (ps. 1 ayat 5 dan 6). Kegiatan evaluasi tersebut meliputi penyusunan: 1. Penyajian Evaluasi Lingkungan (PEL); 2. Kerangka Acuan (KA) bagi SEL: dan 3. Studi Evaluasi Lingkungan (SEL).

1.3. Penyusunan PIL adalah aktivitas pertama yang dilakukan oleh sebuah tim atas nama pemrakarsa, dan diajukan kepada instansi yang bertanggung jawab terhadap jenis kegiatan pem. bangunan yang bersangkutan. bagi proyek pusat. atau kepada $\mathrm{Gu}$ bernur Kepala Daerah Tingkat I untuk kegiatan pembangunan yang berada di bawah wewenangnya (ps. 1 ayat 8 ). Melalui penilaian oleh komisi yang dibentuk khusus untuk itu. instansi yang berwenang atau Gubẹrnur memberikan ijin untuk go project Tetapi apabila komisi penilai melihat bahwa berdasarkan PIL diperkira. kan ada dampak penting yang timbul. maka instansı yang berwenang atau Gubernur mewajibkan kepada pemrakarsa kegiatan untuk me nyusun ANDAL, setelah didahului dengan penyusunan KA (ps. 10 dan 12).

Komisi yang memberikan penilaian sebagaimana terpapar di atas, terdapat di pusat maupun daerah. Komisi pusat dibentuk oleh menteri atau pimpinan lembaga pemerintah non-departemen yang bersangkutan dengan jenis kegiatan pembangunan Sedang komisı daerah dibentuk oleh Gubernur Kepala Daerah Tingkat I (ps $2: 3$ sampai dengan 27).

Komisi pusat terdirı atas anggota tetap dan anggota tidak tetap Anggota tetap meliputi unsur struktural dalam lingkungan depar temen atau lembaga non-departemen yang bersangkutan. wakil yang ditunjuk Mendagri, wakil menteri yang ditugasi mengelola lingkungan hidup, dan para ahli dalam bidang terkait Sedang anggota tidak 
tetap diangkat dari unsur departemen atau lembaga non-departemen yang berkepentingan, serta anggota lain yang dipandang perlu.

Komisi daerah juga terdiri atas anggota tetap dan anggota tidak tetap. Anggota tetap terdiri atas unsur BAPPEDA, instansi pemerintah yang bertugas mengelola bidang lingkungan hidup di daerah, dan pusat-pusat penelitian lingkungan hidup (PPLH/PSL) di lingkungan perguruan tinggi pada daerah yang bersangkutan. Sedang anggota tidak tetap diangkat dari unsur pemerintah yang secara sektoral berwenang di daerah. BKPMD, serta anggota lain yang dipandang perlu.

1.4. Kerap kali wilayah kepentingan manusia yang terkena dampak pembangunan hanya dibayangkan secara sempit, terutama yang bersifat fisik, kimiawi, dan biologis saja. Dalam kaitan ini Munn (1979) menyajikan suatu daftar yang cukup baku dari wilayah kepentingan manusia yang kemungkinan terkena dampak ke dalam 14 kategori. Pada salah satu kategori wilayah kepentingan manusia yang kemung. kinan terkena dampak kegiatan pembangunan, yaitu kategori kesejahteraan fisik (physical amenities), Munn mencantumkan aspek monumen sejarah dan arkeologi di dalamnya. Secara keseluruhan daftar yang diajukan oleh Munn tersebut meliputi pula kemungkinan dam. pak pada lingkungan sosial, ekonomi. dan budaya.

Keberadaan aspek sejarah dan arkeologi dalam setiap prakiraan dan evaluasi dampak kegiatan pembangunan merupakan wawasan yang selaras dengan salah satu tujuan disiplin arkeologi itu sendiri. Iklim semacam ini memberikan ruang gerak yang lebih leluasa bagi kalangan arkeologi untuk terjun langsung dalam kegiatan pembangunan secara umum di satu pihak, dan pelestarian data arkeologi di pihak lain.

Pelaksanaan ANDAL yang mencantumkan aspek arkeologi merupakan satu pilihan yang dirasa perlu di Indonesia. Bagi kalangan arkeologi khususnya. ANDAL menggarisbawahi upaya perlindungan benda cagar budaya nasional yang telah digariskan dalam Monumenten Ordonnantie Stb. 238 Tahun 1931 yang hingga kini masih ber- 
iaku. Manfaat ANDAL lebih dirasakan mengingat dewasa ini perundangan produk tahun 1931 tersebut dirasa telah tidak efektif. Di lain pihak, Undang-undang tentang Benda Cagar Budaya, yang diharapkan lebih berfungsi efektif, belum siap untuk diundangkan (Koesnadi, 1983/1984).

2.1. Menurut Otto Soemarwoto (1983) dan Emil Salim (1986), pembangunan dan pembinaan lingkungan adalah sejoli yang tidak dapat dipisahkan. Bagaimanapun juga pembangunan dapat dan telah menimbulkan permasalahan lingkungan yang pada gilirannya akan mengurangi, atau bahkan meniadakan manfaat pembangunan itu sendiri. Oleh karena itu masalahnya bukanlah mempertanyakan apakah membangun atau tidak, melainkan bagaimanakah membangun secara bijaksana dan dapat menaikkan kualitas lingkungan yang terdukung dan terlestarikan. Dengan demikian, apabila pembinaan lingkungan meliputi pula bidang budaya, dalam kaitan ini aspek arkeologi, maka kegiatan pembangunan sewajarnyalah mempertimbangkan resiko yang dibebankan pada tinggalan arkeologis sebagai konsekuensi damnak yang diakibatkan oleh kegiatan pembangunan (Martono, 1982/1983).

Selama ini dampak negatif terhadap segala bentuk tinggalan arkeologis masih sepenuhnya merupakan biaya (cost) eksternal dari kegiatan pembangunanyang mengakibatkannya, serta menjadi beban sepenuhnya bagi pihak pengelola benda cagar budaya. Artinya, manfaat dan dampak negatif suatu kegiatan pembangunan, masingmasing dirasakan oleh sebagian anggota masyarakat yang berlainan. Dalam skala makro kepentingan nasional, biaya yang diperhitungkan atas resiko tersebut seringkali cukup besar, atau bahkan lebih besar daripada manfaat yang diperoleh. Hal ini dapat terjadi karena tinggalan arkeologi sebagai benda cagar budaya memiliki nilai yang tinggi dan kerapkali tidak dapat ditritung dengan jumlah nilai tukar tertentu.

Dampak. negatif berupa pencemaran, vandalisme, atau bahkan pemusnahan benda cagar budaya sebagaimana disajikan melalui beberapa informasi arkeologi (Wibowo 1981; Soediman; 1985), lahir 
terutama karena berbagai kegiatan pembangunan selama ini hanya berorientasi pada kelayakan teknis dan ekonomis semata. Dengan rujukan pada kelayakan lingkungan, terutama lingkungan budaya, diharapkan kegiatan pembangunan tidak akan merugikan tinggalan arkeologis.

2.2. Penyusunan ANDAL, sebagaimana telah berlangsung dewasa ini, tidak dengan sendirinya melibatkan arkeologi di dalamnya. Banyak pelaksana ANDAL menutup mata, atau karena belum sepenuhnya paham, terhadap aspek arkeologi pada tahap 'scoping' penyusunan aktivitas ANDALnya. Dalam kaitan ini secara khusus perlu dicatat bahwa Lembaga Ekologi Universitas Padjadjaran, Bandung, telah dengan konsisten memprakarsai keterlibatan bidang arkeologi dan -juga sejarah dalam beberapa aktivitas ANDALnya (Institute of Ecology Padjadjaran University Bandung, 1980; Panggabean, 1985a; 1985b; Mundardjito, 1983). Sèmentara itu penyertaan pihak arkeologi dalam penyusunan ANDAL berbagai kegiatan pembangunan yang lain masih cenderung merupakan inisiatif dari kalangan arkeologi sendiri.

Menuju era 'tinggal landas' dewasa ini, kegiatan pembangunan di seluruh wilayah Indonesia dinilai cukup tinggi intensitasnya. Sejajar itu disadari pula bahwa di seluruh wilayah yang sama terdapat pula agihan (distribution) tinggalan arkeologis dalam intensitas yang beragam. Agihan tinggalan arkeologis di Pulau Jawa dapat dikatakan hampir selalu terdapat di setiap wilayah Desa (Kelurahan). Hasil-hasil penelitian arkeologi yang terbaru menunjukkan kecenderungan bahwa kepadatan tinggalan arkeologis di luar Pulau Jawa tidak jauh berbeda dengan di Jawa. Masalahnya, tinggalan-tinggalan arkeologis tersebut, untuk sebagian besarnya, tidak dijumpai di permukaan tanah melainkan di bawah permukaan tanah atau air.

Faktor yang terakhir ini yang tampaknya mendorong absennya rujukan arkeologi dari berbagai aktivitas penyusunan ANDAL. Tidak nampaknya tinggalan arkeologis di muka tanah mengakibatkan kajian 
dampak terhadap tinggalan arkeologis luput dalam 'scoping'. Sehing. ga wajar kiranya dalam berbagai kegiatan pembangunan, baik yang berskala besar maupun kecil, dijumpai kemudian, dan telah menjadi terganggu tentunya, benda-benda cagar budaya di dalam areal proyek kegiatannya.

Memperhatikan karakter keberadaannya, maka tinggalan arkeologis memiliki potensi yang tinggi untuk terkena dampak. Dinilai berpotensi tinggi karena tinggalan arkeologis didapatkan hampir merata di seluruh wilayah, mulai dari bawah muka air sampai ke puncak gunung, serta tidak selalu dapat diketahui dengan dini karena sebagian besar tidak langsung dengan mudah dapat diamati keberadaannya.

2.3. Dalam penyusunan ANDAL terdapat aktivitas interpretasi dampak. Interpretasi dampak merupakan penggambaran seberapa jauh dampak yang dihasilkan oleh suatu kegiatan pembangunan terhadap aspek tertentu, misalnya benda cagar budaya. Dengan demikian akan dihasilkan suatu besaran yang memiliki bobot perbandingan tertentu terhadap indeks toleransi dari benda cagar budaya yang bersangkutan.

Aktivitas di atas merupakan hal yang secara nisbi mudah dilakukan terhadap aspek fisik, kimiawi, dan biologis. Sebaliknya aktivitas tersebut relatif lebih sulit bagi aspek sosial, ekonomi, dan bu. daya, mengingat ketiga aspek yang terakhir ini memiliki dimensi yang lebih rumit dan selalu berubah. Kesulitan yang ada terutama dijumpai pada aktivitas pengukuran besaran suatu dampak, maupun pada penetapan nilai ambang batas toleransi yang diperkenankan bagi ketiga aspek yang terakhir tersebut. Baku mutu lingkungan yang bertautan erat dengan aktivitas-aktivitas di atas pun sampai dengan saat ini belum tersedia. Di lain pihak, penyusunan baku mutu lingkungan di Indonesia bagi aspek-aspek fisik, kimiawi, dan biologis yang meliputi media air, udara, dan tanah, relatif telah lebih menemukan bentuknya. 
Bagi tinggalan arkeologis, penentuan baku mutu serta metoda yang tepat dalam penaksiran dampak merupakan suatu masalah yang perlu mendapatkan perhatian serius. Tanpa suatu pola yang baku, dikhawatirkan keikutsertaan kalangan arkeologi dalam aktivitas ANDAL tidak terkoordinasikan bagi kepentingan arkeologi itu sendiri. Dikhawatirkan pula hasilnya terlalu bersandar pada subjektivitas pakar arkeologi penyusun ANDAL. Dengan kata lain, rekomendasi yang dihasilkan oleh penyusun ANDAL akan sulit dipertanggung. jawabkan kepada kalangan arkeologi secara khusus.

Ketersediaan pola yang baku dalam penyusunan ANDAL bagi benda cagar budaya akan memudahkan penyusun ANDAL untuk memformulasikan rekomendasi terhadap suatu kegiatan pembangunan. Perlu ditambahkan, bahwa menurut Munn (1979) serta Lang dan Armour (1981), rekomendasi tersebut terdiri dari empat pilihan yaitu:

1. Proyek diterima sepenuhnya karena tidak ada dampak negatif bagi lingkungan;

2. Proyek disetujui, dengan mitigasi tertentu bagi dampak yang ditimbulkannya;

3. Menyarankan alternatif proyek kegiatan pembangunan yang lain atau penentuan secara lebih cermat dampak negatif yang muncul; dan

4. Proyek ditolak, karena dampak negatifnya terlalu berbahaya.

3.1. Sebagaimana dipaparkan di atas, ANDAL mendorong eksternalitas biaya yang menjadi beban masyarakat ke arah internalitas biaya sebagai beban pemrakarsa kegiatan pembangunan. Berdasarkan hasil_penyusunan ANDAL bagi aspek arkeologi maka segala kerugian yang dirasakan oleh kalangan arkeologi dapat dikurangi secara optimal. Penanggulangan dampak tidak lagi merupakan beban bagi instansi pengelola benda cagar budaya, melainkan merupakan kewajiban pemrakarsa kegiatan yang memasok dampak. 
Telah pula disinggung, bahwa untuk semua ini pihak kalangan arkeologi seyogyanya menata diri. Penataan diri sebagai prakondisi yang dirasa mendesak tersebut meliputi dua masalah utama. yaitu 1. Pemolaan metode lapangan dan identifikasi dampak, serta pene tapan baku mutu untuk lingkungan arkeologi yang dikaitkan dengan rekomendasi sebagai produknya; 2. Peranserta kelembagaan arkeo. logi dalam penyusunan ANDAL.

3.2. Penetapan baku mutu lingkungan arkeologi serta pemolaan me toda lapangan dan interpretasi dampak tidak akan ditelaah secara khusus di dalam tulisan singkat ini. Butir ini sebenarnya lebih meru pakan 'pekerjaan rumah' bagi kalangan arkeologi Indonesia pada umumnya. Perumusan ke arah itu seyogyanya melibatkan berbagai lembaga yang berkaitan dengan disiplin arkeologi. Selain itu diper lukan pula dialog dengan kalangan 'luar' arkeologi, khususnya kantor menteri yang ditugasi mengelola lingkungan hidup serta pusat-pusat penelitian lingkungan hidup di lingkungan perguruan tinggi (PPLH; PSL).

3.3. Penyusunan ANDAL sebagaimana tertuang dalam PP 29, telah dilengkapi dengan berbagai komponen kelembagaan. Komponen kelembagaan yang dinilai berkaitan erat dengan peranserta kalangan arkeologi, adalah: 1. Pelaksana (tim) ANDAL; 2. Komisi Penilai: dan 3. Komunikasi hasil ANDAL. Komponen-komponen kelembagaan tersebut mencakup seluruh proses penyusunan ANDAL sejak PIL sampai dengan penetapan status kegiatan pembangunan yang ber sangkutan oleh instansi yang berwenang.

Peranserta lembaga-lembaga arkeologi dengan sendirinya ber gayut pada komponen-komponen ANDAL di atas. Kegiatan pelak. sanaan ANDAL (PIL, KA, ANDAL, RKL, RPL), misalnya, memiliki pertautan erat dan merupakan wewenang instansi penelitian arkeo logi (Pusat Penelitian Arkeologi Nasional, Balai Arkeologi) dan instan. si perlindungan/pembinaan tinggalan arkeologis (Direktorat Perlin. dungan dan Pembinaan Peninggalan Sejarah dan Purbakala, Suaka 
Peninggalan Sejarah dan Purbakala). Hal ini diselaraskan dengan Keputusan Mendikbud No.: 0222 g/O/1980 Bab V ps. 112 - 136; 0207/O/1978; 0427/O/1981; 0222 e/O/1980 Bab VI ps. $104-$ 126; 0428/O/1981 Bab III ps. $49-50$.

Aktivitas instansi penelitian arkeologi dalam penyusunan ANDAL, antara lain, adalah memastikan ada/tidaknya tinggalan arkeologis pada area kegiatan pembangunan. Selain itu juga menentukan intensitas benda cagar budaya di areal tersebuit mêtáliui metode-metode penelitian arkeologis yang terkendali. Seandainya di area yang bersangkutan didapati tinggalan arkeologis serta telah dipastikan intensitasnya, bersama-sama dengan instansi perlindungan/pembinaan dilaksanakanlah pengidentifikasian dampak terhadap tinggalan arkeologis tersebut. Kemudian instansi perlindungan/pembinaan secara khusus merumuskan treatment yang harus dilakıkan, terutama melalui penyusunan RKL dan RPL.

Patut digarisbawahi pendapat Bissett (1984), bahwa dampak memiliki sifat spatial. Artinya, dampak dapat berlangsung di area kegiatan pembangunan maupun di kawasan yang menjauhi area kegiatan asal. Dengan demikian penelitian arkeologis sebaiknya tidak dibatasi pada area kegiatan pembangunan semata, tetapi juga kawasan di sekitarnya yang diperkirakan berpotensi terkena dampak.

Peranserta kalangan arkeologi dalam ANDAL tidak terbatas pada komponen penyusun ANDAL saja tetapi juga kesertaannya pada komisi penilai. Keikutsertaannya sebagai anggota K̂ rupakan konsekuensi logis dari keikutsertaan arkeologi datam penyusunan ANDAL. Bahkan keikutsertaan kalangan arkeologi dalam sebanyak-banyaknya keanggotaan komisi penilai merupakan hal yang positif, setidak-tidaknya dalam memantau peruntukan area/lahan bagi berbagai kegiatan pembangunan. Dalam kaitan ini dirasa tepat seandainya keanggotaan dalam komisi penilai diemban oleh kalangan perguruan tinggi, khususnya staf edukatif pada bidang studi arkeologi. 
Keterlibatan kalangan arkeologi dalam penyusunan ANDAI. tidak hanya berhenti sampai di situ. Keterlibatan tersebut meliputi pula aktivitas pada tahap komunikasi hasil ANDAL, yang melibat. kaan pula pihak pengambil keputusan dan pihak-pihak lain yang berkepentingan. Kelembagaan komunikasi hasil ANDAL yang dijabarkan dalam bentuk dengar pendapat (inspraak, community hearings. citizen panels, planningcells, citizen review boards) memberikan kesempatan kepada masyarakat luas guna turut memberikan penilai. an kepada hasil penyusunan ANDAL suatu kegiatan pembangunan. Keterlibatan kalangan arkeologi dalam lembaga ini disalurkan melalui Ikatan Ahli Arkeologi Indonesia (IAAI) sebagai suatu kelompok profesi yang mandiri. Dalam penjelasan ps. 19 UULH. kelompok profesi tercakup dalam lembaga swadaya masyarakat (LSM) yang berperan sebagai penunjang bagi pengelolaan lingkungan hidup secara luas.

4. Keterlibatan aspek arkeologi dalam proses penentuan status suatu kegiatan pembangunan bukanlah hal yang asing di berbagai negara maju (Soediman, 1985). Demi kelestarian benda cagar budaya, aspek arkeologi diperhitungkan kehadirannya serta dipandang sebagai salah satu bahan pertimbangan yang tidak kalah pentingnya dibandingkan dengan aspek kehidupan yang lain.

Dalam hal ini memang kalangan arkeologi dituntut untuk secara sadar merubah orientasi wawasan profesionalismenya, dari dialog tertutup di kalangan sendiri ke dialog terbuka dengan kalangan yang lebih luas. Iklim semacam ini dinilai efektif untuk menanamtumbuh. kan persepsi positif di kalangan luas terhadap warisan budaya bangsa, khsusnya tinggalan arkeologis. Bagaimanapun juga perlu disadari, bahwa warisan budaya tersebut merupakan masterpiece-masterpiece kreativitas pemikiran. perasaan. dan cucuran keringat bangsa di masa yang lampau (Harsja, 1980/1981).

Ketidakterlibatan aspek arkeologi dalam berbagai aktivitas ANDAL. sebagaimana telah dipaparkan pada butir 2.2. di atas, kemungkinan besar disebabkan oleh faktor ketidaksadaran, dan bukan 
ketidaktahuan. Sebagai buktinya dapat ditunjukkan, bahwa hampir semua, terdapat juga yang tidak, kursus ANDAL yang diselenggarakan oleh PPLH/PSL perguruan tinggi atas koordinasi Menteri Negara $\mathrm{KLH}$, tidak mencantumkan 'dampak kegiatan pembangunan terhadap benda cagar budaya/tinggalan arkeologis' sebagai materi khusus yang diberikan. Padahal dampak semacam itu bukan hal yang asing bagi masyarakat karena telah cukup sering dilansir melalui media massa, daerah maupun nasional.

Kecenderungan untuk tidak melibatkan arkeologi dalam aktivitas penyusunan ANDAL merupakan suatu hal yang dinilai 'berbahaya'. Kecenderungan tersebut dikhawatirkan semakin menonjol manakala penyusunan ANDAL dipindahkelolakan dari pihak PPLH/PSL perguruan tinggi kepada pihak swasta (consultant) pada masa yang mendatang. Penanganan ANDAL secara komersial akan mendorong pelaksana (tim) ANDAL memperkecil sesempit mungkin scoping aktivitasnya guna keuntungan yang lebih tinggi. Untuk kekhawatiran seperti ini akan lebih baik apabila penanggulangannya dilandasi oleh pedoman yang minimal berbobot setingkat Keputusan Menteri.

Sejalan dengan itu, pemasyarakatan aktivitas ANDAL yang telah melibatkan aspek arkeologi merupakan sarana dan media yang efektif guna mewujudkan maksud di atas. Sebagaimana diketahui dewasa ini beberapa terbitan arkeologi telah melaporkan hasil penelitian arkeologi yang tercakup sebagai bagian dari aktivitas ANDAL. Tentunya pada masa mendatang terbitan-terbitan semacam itu akan semakin bertambah jumlahnya, dan akan juga meliputi aktivitas perencanaan mitigasi dampak serta pemantauannya. Suatu langkah yang bijaksana apabila terbitan-terbitan tersebut dikomunikasikan kepada lembaga-lembaga semacam PPLH/PSL perguruan tinggi dan instansi-instansi lain yang bertaut dengan aktivitas ANDAL. Pemahaman melalui informasi yang diperoleh dari terbitan-terbitan tersebut diharapkan mendorong proses internalisasi pengetahuan tentang dampak kegiatan pembangunan terhadap benda cagar budaya di kalangan para pengelola lingkungan hidup. Dengan demikian 


\section{akan bersambutlah upaya pelestarian data arkeologis, sesuai dengan}

peruntukannya bagi kepentingan arkeologi secara luas.

Penyusunan dan penyelesaian tulisan ini tidak terlepas dari bantuan berbagai pihak. Untuk itu disampaikan terimakasih kepada Bapak Drs. Goenadi Nitihaminoto. Kepala Balai Arkeologi Yogyakarta, atas kesempatan yang diberikan untuk dapat mengikuti Kursus Dasar Analisis Mengenai Dampak Lingkungan Angkatan VI 1986 PPLH UGM - KMN KLH. Penghargaan yang serupa disampaikan pula kepada seluruh staf Balai Arkeologi Yogyakarta atas dukungan yang diberikan. 


\section{RUJUKAN}

Bissett, Ronald. 1984. "Selected ElA Method: An Introduction". Paper Presented at the International Training Course on Environmental Impact Assessment and Land Use Planning, Hongkong, 16 - 21 lanuary.

Emil Salim. 1986. Pembangunan Berwawasan Lingkungan. Iakarta: Penerbit LP3ES.

Harsja W. Bachtiar. 1980/ 1981. "Kreativitas: Usaha Memelihara Kehidupan Budaya". Analisis Kebudayaan, Tahun 1/2. Departemen Pendidikan dan Kebudayaan.

Institute of Ecology Padjadjaran University Bandung. 1980. Environmental Analysis of the Saguling Dam: Mitigation of Impact.

Kantor Menteri Negara Kependudukan dan Lingkungan Hidup. 1986. Peraturan Pemerintah Republik Indonesia Nomor 29 Tahun 1986 tentang Analisis Mengenai Dampak Lingkungan.

Kantor Menteri Negara Pengawasan Pembangunan dan Lingkungan Hidup. 1982. Undangundang Republik Indonesia Nomor 4 Tahun 1982 tentang Ketentuan-ketentuan Pokok Pengelolaan Lingkungan Hidup.

Koesnadi Hardjasoemantri. 1983/ 1984. "Peranan Arkeologi dalam Pembangunan, Dilihat dari Sudut Peraturan Perundang-undangan di Bidang Lingkungan Hidup". Analisis Kebudayaan, Tahun IV/ 3. Departemen Pendidikan dan Kebudayaan.

Lang, R. and A. Armour. 1981. The Assessment and Review of Social Impacts. Ottawa : FEARO.

Martono, Yuwono. 1982/ 1983. "Masalah Pelestarian Lingkungan Hidup Manausia Suatu Pendekatan Pemugaran". Analisis Kebudayaan, Tahun III/ 1. Departemen Pendidlkan dan Kebudayaan.

Mundardjito. 1985. "Studi Kelayakan Arkeologi di Indonesia". Pertemuan Ilmiah Arkeologi ke III Ciloto, 23-28 Mei 1983. Iakarta: Proyek Penelitian Purbakala Departemen Pendidikan dan Kebudayaan.

Munn, RE. 1979. Environmental Impact Assessment, Scope 5. New York : Iohn Wiley \& Sons. 
Otto Soemarwoto. 1983. Ekologi, Lingkungan Hidup dan Pembangunan. Djambatan.

Panggabean, J. Ratna Indraningsih, et. al. 1985a. "Laporan Penelitian Arkeologi di Daerah Calon Genangan Waduk Kedung Ombo Jawa Tengah" Berita Penelitian Arkeologi. Nomor 31. Jakarta: Proyek Penelitian Purbakala Departemen Pendidikan dan Kebudayaan.

Panggabean, J. Ratna Indraningsih, et. al. 1985b. "Pemukiman Arkeologi di Daerah Calon Genangan Waduk Cirata, Cianjur, Jawa Barat". Pertemuan Ilmiah Arkeologi Ke III Ciloto, 23-28 Mei 1983. Jakarta: Proyek Penelitian Purbakala Departemen Pendidikan dan Kebudayaan.

Soediman. 1985. "Peranan Arkeologi dalam Pembangunan Nasional". Pertemuan Ilmiah Arkeologi Ke III Ciloto, 23-28 Mei 1983. Jakarta: Proyek Penelitian Purbakala Departemen Pendidikan dan Kebudayaan.

Wibowo. A.S. 1981. "Mengikuti Ekskavasi Candi di Daerah Wonogiri, Jawa Tengah". Kalpataru, Nomor 7. Jakarta: Proyek Penelitian Purbakala Departemen Pendidikan dan Kebudayaan. 


\section{Lampiran 1.}

Regional Development Projects

that may Produce Environmental Impacts

1. Land use and transformation Urban; Industrial; agricultural; airport; transportation; transmission lines; offshore structures.

2. Resource extraction

Drilling: mining; blasting; lumbering: comercial fishing and hunting.

3. Resource renewal

Reforestation; wildlife management; fertilization; waste recycling; flood control

4. Agricultural processes

Farming; ranching: dairying; feed lots; irrigation

5. Industrial processes

Iron and steel mills; petrochemical indus. try: smelters; pulp and paper plants

6. Transportation

Railways; aircraft; automobiles; trucks: shiping: pipelines

7. Energy

Mand-made lakes; dams; oil; coal-fired and nuclear power stations.

8. Water disposal and treatment Ocean dumping; land fill; environmental contaminants and toxic substances; underground storages: biological emissions

9. Chemical treatment Insect control (pesticides); weed control (herbicides).

10. Recreation Hunting areas; parks; resort development; allterrain vehicles.

(Munn, 1979) 


\section{Lampiran 2.}

\section{Areas of Human Concern (Impact Categories)}

1. Economic and occupational Displacement of population; relocation of status population in response to employment opportunities; services and distribution patterns: property values.

2. Social pattern or live style Resettlement; rural depopulation; chánge in population density: food; housing: material goods; nomadic: settled; pastoral agricultural; rural; urban.

3. Social amenities and relation-Family life styles; schools; transportation ships community feelings; participation vs alienation; local and national pride vs regret: stability: disruptions: language. hospitals: clubs; recreation: neighbour liness.

4 Psychological features

Involvement; expectations; stress. trusta tions: commitment: challenges work satisfaction; national or community pride freedom of choice: stability and continuity self expression: company or solitude mobility.

5. Physical amenities (intellec- National parks; wildlife; art galleries and tual. cultural aesthetic. and museums; concert halls. hisioric and sensual) archaeological monuments. beauty of landscape: wilderness: quiet clean air and water

o. Health

Changes in health: medical services. me dical standards

7. Personal security

Freedom from molestation freedom from natural disasters

8. Religion and traditional belief

Symbols; taboos; values 
9. Technology

10. Cultural

11. Political

12. Legal

13. Aesthetic

14. Statutory laws and acts
Security: hazards, safety measures. benefits: emission of wastes: congestion: density.

Leisure: fashion and clothing changes: new values; heritage: traditional and religious rites

Authority: level and degree of involvment: priorities. structure of decision-making: responsibility and responsiveness: resource allocation; local and minority interests: defence needs: contributing or limiting factors: tolerances

Restructuring of administrative manage ment: changes in taxes; public policy.

Visual physical changes; moral conduct: sentimental values

Air and water quality standards: safety standards; national building acts: noise abatement by-laws.

(Munn, 1979) 